\title{
The War of the Worlds May Well Start in Latin America
}

\section{Gabriela Alemán's Filmmaking Approach of Writing and the Decentring of Global Narratives}

\author{
Luis A. Medina Cordova | ORCID: 0000-0002-7763-6811 \\ King's College London, London, UK \\ luis.medina@kcl.ac.uk
}

\begin{abstract}
This article analyses the literature-cinema dialogue established by the Ecuadorian writer Gabriela Alemán in her short story collection La muerte silba un blues (2014). Firstly, I revise how Alemán borrows the production methods of the cult Spanish filmmaker Jesús "Jess" Franco to craft a collection that aids us to see the world as an interconnected whole. Secondly, I close read the story that opens the collection, El extraño viaje, which takes Orson Welles' radiophonic adaptation of The War of the Worlds to the Ecuadorian context. My argument is that, in making the city of Quito the target of H.G. Wells' Martian invasion, Alemán engages with a rich history of multimedia adaptations and places Ecuador's capital at the centre of a global narrative. I argue that her work decentres and recentres world literature dynamics where Latin American literature in general, and Ecuadorian writing in particular, sit at the periphery of world literary systems.
\end{abstract}

\section{Keywords}

Gabriela Alemán - Latin American World Literature - contemporary Ecuadorian literature - Jess Franco

In the introduction of her short story collection La muerte silba un blues (2014), the Ecuadorian writer Gabriela Alemán (1968) posits the following question: "what would happen if a book of fiction borrows the production methods 
of a film director?" (4). ${ }^{1}$ To further complicate the query, one may add that Alemán is not referring to any director, but to one who has been deemed "perverted" by his critics and "perverse" by his admirers: the cult Spanish filmmaker Jesús "Jess" Franco (1930-2013). The clarification means everything. Because one thing would be to borrow from, say, the meticulous filmmaking of Alfred Hitchcock. Another completely different is to borrow from Franco, an exploitation and B-movies director whose very filmography remains contested (critics debate whether he should be credited for a number of films that ranges from 140 to some 200, and includes horror films, science fiction, noir, and pornographic movies); a transnational filmmaker with a tendency for working in different countries, changing his name accordingly (he became Franco Manera in Italy, Jess Frank in Germany, Clifford Brown in France); a prolific auteur (in)famous for his alleged practice of shooting footage for two or three movies at once with the same crew and cast, and later renaming / repackaging the same film into several versions to cater to different European markets.

Alemán borrows from Franco's filmmaking technique to craft a collection of stories that, much like the opus of the director it pays homage to, stubbornly refuses to submit to the lens of a single perspective. La muerte silba un blues is, at once, literature conceived of as cinema and cinema fleshed out by literature. But more importantly for what I argue in this essay, it is uncompromisingly world literature as much as Ecuadorian national literature.

This article proposes to read Alemán's dialogue with Franco in light of contemporary world literature theorisations. My reading pays close attention to the particularities of the Ecuadorian context, which frames Alemán's writing without compromising its engagement with the world at large. In this sense, my proposal is twofold. Firstly, I analyse how La muerte silba un blues appropriates Franco's cinematic methods to argue that, through a structural relation with cinema that blurs genre and storytelling boundaries, Alemán's writing articulates a sense of what Héctor Hoyos calls globality, i.e. "the literary representation of a broadening consciousness of the world as a whole" (2). By doing so, it engages with world literature, understood not only as a field of study concerned with fiction that is translated and circulates beyond national borders but also with fiction that enables us to imagine the world.

The second part of this essay focuses on one of La muerte silba un blues' stories to argue that Alemán's positionality informs her globality. I revise how $E l$ extraño viaje, the story that opens the collection, takes Orson Welles' radiophonic adaptation of The War of the Worlds to the Ecuadorian context. My

1 Translations of selections from La muerte silba un blues are mine throughout. 
argument is that, in making the city of Quito the target of H.G. Wells' Martian invasion, Alemán engages with a rich history of multimedia adaptations, placing Ecuador's capital at the centre of a global narrative. As such, I argue, her work decentres and recentres world literature dynamics where Latin American literature in general, and Ecuadorian writing in particular, sit at the periphery of world literary systems. Moreover, by making Quito a crucial component of her story, Alemán creates a fiction that imagines the world while remaining rooted in Ecuador. In doing so, I conclude, her work enables a path for considering that dismissing national frameworks needs not to be the natural condition for fiction to be thought of globally. In dialogue with other critical perspectives about the meanings of world literature as construed from Latin American contexts, my analysis suggests that we can study and build the global by thinking through the nuances of national historiographies.

Like the title of the collection itself, borrowed from a 1964 Jess Franco movie, the ten stories that comprise La muerte silba un blues (Death Whistles the Blues) are named after films connected to Franco's universe. While El diabólico Dr. $Z$ (The Diabolical Dr.Z) and Fu Manchúy el beso de la muerte (Fu Manchú and the Kiss of Death) are named after films directed by Franco in 1966 and 1968 respectively, El extraño viaje (The Strange Voyage) refers to one where Franco has a prominent acting role (Fernando Fernán Gómez's homonymous 1964 drama, which I discuss in the next section of this essay). This titling strategy is prone to confusion: it is not only that there are previous films identically named but also that there are no characters called Fu Manchú or Dr. Z in the stories. However, the confusion is far from accidental. From the very beginning, Alemán argues that she appropriates the "production techniques of one of the most singular directors in the history of cinema" (4). Ambiguity, deception, and confusion are precisely part of the "singularities" that constitute Franco, "the world's most dangerous filmmaker"(Todd 9).

Perverted, perverse or dangerous, the ways of talking about Franco in scholarly texts, the media or fandom share a similar halo of referring to a unique subject matter. Antonio Lázaro-Reboll and Ian Olney explain the uniqueness attributed to Franco by arguing that his work - eccentric, unruly, and rebellious - makes him hard to pin down as a filmmaker:

His work presents us with many different, often conflicting, faces. It seems, simultaneously, to be the product of a marginalised artist and 
a commercial hack; a horror specialist and a genre agnostic; a Spanish national and a rootless exile; a feminist eroticist and a misogynistic pornographer; a relic of the grind-house era and an apostle of the digital age. Multifaceted and paradoxical, it is a body of films at war and obsessed with itself.

Lázaro-Reboll and Olney's point is that Franco's filmography resists exclusionary interpretative frameworks, complicating classification attempts. In their view, not even auteur theory can fully tame Franco's oeuvre: there are many arguments to consider him a cult auteur, yet his movies seem to defy fundamental assumptions about film authorship. "In short, it is never a question of 'either / or' with Franco's work, but always of 'both / and'" (Lázaro-Reboll and Olney 30). Like a Franco movie, Alemán's La muerte silba un blues refuses to submit to the discipline of a single perspective. This section focuses on the ways in which Alemán appropriates Franco's methods to blur boundaries both within and beyond the text. In her collection, Alemán follows Franco's filmmaking logic to this effect in two main ways. First, she makes characters represent types so they can jump indistinctively from one plot to another, transgressing the limits of their stories and those of the collection itself. Second, she traverses a mixture of fiction genres, critically engaging with the Gothic and problematising the limitations of Latin American and Ecuadorian writing. These strategies work together to foreground a mutual embeddedness between cinema and literature while also articulating globality. Thereby, La muerte silba un blues becomes able to participate in the creation and recreation of narratives of the global, relating to world literature's concerns even when it remains untranslated.

In creating her collection, Alemán's foremost borrowed strategy relates to seriality and repetition, which are easily identifiable features of Franco's work. In his movies, characters, themes, and plots frequently recur, mutating from one to another and spanning the entirety of his career. Tim Lucas discusses how Franco often retold similar stories in different forms, different periods and different tenses, stressing that the director himself once said "that his entire, sprawling filmography could probably be condensed to as few as eight recurring plots" (19). Thematic groupings range from vampirism and mind control to necrophilia and cannibalism, with stories traversed by uncanny female sexuality and violent erotism. Characters are an essential part of the repetition cycle. Franco's movies are populated by mad scientists, secret agents, detectives, avenging angels, and among others, lesbian vampires. Lucas notes that, in a Franco film, stock names signal what kind of person/creature is to be encountered: "Morpho or Matthias (henchman), Eugenie (defiled inno- 
cent), Radeck (villain or corruptor), Tanner (hero), Kallman or Seward (doctor), Irina or Nadine (vampiric female), Lorna (demonic female), Melissa (destroyed beauty)" (20). Characters commonly represent types connected to a handful of recurring names in a filmography that comprises some two hundred titles.

Alemán takes the idea of making characters recur for structuring La muerte silba un blues. In her collection's introduction, she advises readers that the same characters appear in several stories because - similar to a Franco movie - they represent types: "woman, 36 years old, tall, with an oval face; old man, 85 years, hunched back, alone; man, 37 years, sharp face, insecure" (4). The protagonists, Alemán explains, crawl from one story to the other fuelled by the same existential suffocation:

The first part of this book is built on two long stories - the Martian landing orchestrated by a radio station in Quito in 1949, and a Central European migrant's journal in 1940 s Ecuador. The same woman cursorily appears in both stories and becomes the centre of a third one, while a 26 -year-old man reappears at 85 in the fourth.

Characters jump from one plot to another to transgress the borders of their stories and defy the limits of the collection itself. This is exemplified by the 85-year-old man of the fourth story (El diabólico $\mathrm{Dr}$. Z), who is 26 in the first (El extraño viaje). He reappears in the last piece, Al otro lado del espejo (On the Other Side of the Looking Glass), playing the role of a stubborn elder who refuses to leave his home in a New Orleans soon to be devastated by Hurricane Katrina. However, despite minor changes, La muerte silba un blues is not the first space where an account of this man pops up in Alemán's narrative. Al otro lado del espejo is but a different title for Jam Session, Alemán's contribution to B39: Antología del cuento latinoamericano (2007), an anthology that brings together short stories authored by the first "Bogotá 39" Group. Alemán became one of the B39 in 2007, when she and other 38 writers from the region were named the most influential writers under the age of 40 in Latin America at the Twentieth Bogotá International Book Fair. John Riofrio argues that her presence in that list, which included widely recognisable figures of Latin American letters today such as Junot Díaz and Jorge Volpi, had the effect of "boosting her visibility to a general readership but also dramatically accentuating her status as both a Latin American and an Ecuadorian writer" (17).

In repackaging under a different label one of her old and probably bestknown stories, Alemán is following Franco's logic. The Spanish filmmaker's body of work remains hard to delineate in its entirety partly because many of 
his movies exist in multiple different versions, some after being released "under a dozen titles and in as many versions in various markets and formats over the years" (Lázaro-Reboll and Olney 21). Nevertheless, considering Riofrio's argument that Alemán's inclusion in the B39 list emphasizes her status as a Latin American and Ecuadorian writer, I argue that something else is in operation here. Alemán's work brings together her "accentuated" Latin Americanness and Ecuadorianness with the European character of Jess Franco's cinematic practice, which followed common patterns of other "Eurotrash" directors in the post-war era who were accustomed to making several cuts of their movies targeted at more or less conservative markets and censors (21). Thereby, $L a$ muerte silba un blues sets up a dialogue between Latin America and Europe, one that tests the limits of each cultural space and unsettles exclusionary ideas of belonging to one or the other.

Alemán's collection pushes further the boundaries of cultural belonging by engaging with the mixture of genres Franco transited. One of Franco's major contributions to European exploitation cinema, Tatjana Pavlović explains, is his development of horrotica, i.e. "the wedding of horror and sexuality and denoting cult sensibility, alternative taste, and hipness"(114). Mixture is a staple of Franco's work, a predominant feature shaping an opus that subverts notions of purity. In this sense, it also challenges the idea of the national. Lázaro Reboll and Olney note that Franco developed an international brand of cinema that enables reading him as an exile who problematises the idea of Spain, and Spanish national cinema, in his films (29). In a similar vein but considering also reception, Pavlović argues that Franco's status as a cult film director accentuates the ways in which his work disturbs national boundaries:

His cult followers scattered around the world problematise the notions of the national, the nation, foreign, local, and their interplay. International circulations of Franco's low-budget, cult, trash, B production, and sexploitation films have transnational implications posing questions about co-productions, market, and movements across national borders. His incorporation might thus bring an interesting angle to existing discourses on Spanish cinema, unsettling quests for national specificity.

Despotic Bodies 119

La muerte silba un blues follows in Franco's footsteps by combining gore horror with violent and dangerous eroticism. More relevant for my purpose, however, is the fact that it also refers to the Gothic, one of Franco's regular grounds, which he explored through movies like Gritos en la noche (The Awful Dr. Orlof for international markets, 1962). Gothic here signifies narratives in which the 
disturbing return of pasts upon presents evoke emotions of terror, narratives that condense threats to humanist values through "supernatural and natural forces, imaginative excess and delusion, religious and human evil, social transgression, mental disintegration and spiritual corruption" (Botting 1). The first part of Alemán's collection is precisely marked by harrowing pasts returning to disturb multiple presents in stories packed with excess and transgression. An example of this can be found in the second story that gives also the title of the collection. Fragmentarily, it tells the story of an unnamed woman trapped in a nightmarish state, in which a previous experience of being subdued and abused by a group of men while lying on a bed unable to move recurs over and over to create an inescapable loop of horror. Similarly, Alcaraz - one of the $E l$ extraño viaje's secondary characters - learns two stories later, in El diabólico $D r . Z$, that his past crimes cannot be left behind and that he is condemned to relive them in his old age, slowly walking towards his death in a condition of permanent fear and eeriness.

Alemán's engagement with Gothic fiction, further developed in her 2017 novel Humo, has significant implications for the critical expectations surrounding her Latin American and Ecuadorian writerly status(Medina Cordova 161). She establishes an interaction between what is traditionally considered Latin American and what is not, as the Gothic remains a literary tradition frequently absent from Latin American literary studies. In their analysis of the Gothic in Latin American literature, Sandra Casanova-Vizcaíno and Inés Ordiz argue that Gothic literature is often simplistically associated only with the shadows of European and North American rationalism. Because these associations stress issues of belonging and membership to supposedly non-Latin American categories of writing, Casanova-Vizcaíno and Ordiz explain that, in Latin America, discussions of identity and nationhood have denied readings of Latin American works in a Gothic register. There is a concern that identifying texts as Gothic could be a sign of cultural colonialism. For that reason, they say, there is a predilection among critics for the "realist and/or historical novel, which becomes a nationalist representation of Latin American reality free of outside (colonising) influences" (4). Therefore, it has been widely understood that historical works are prime examples of Latin American writing while Gothic stories are not. The latter might belong almost exclusively to a genre born in and owned by European or North American traditions, championed by the likes of Edgar Allan Poe.

By referring to Franco and Gothic narrative, La muerte silba un blues tests the limitations of Ecuadorian and Latin American writing. Alemán reclaims a literary tradition that is, in theory, beyond the repertoire of Ecuador and Latin America. In this sense, her collection navigates cultural boundaries and con- 
nects them in ten stories that - geographically - stretch over multiple locations in Ecuador, Paraguay, Brazil, the US, and Central Europe. My point here is that Alemán's writing not only foregrounds how literature and cinema are invested in one another, or that literature is in cinema and vice versa, as Robert Stam suggests in his exploration of the "rhizomatic interfaces" across arts, media, and disciplines (2). Alemán's work also conceives and allows readers to imagine a world larger than Ecuador or Latin America, one where national and disciplinary boundaries, more than simple lines of division, are also possibilities for encounter and dialogue. In this light, it is a collection that articulates globality. Hoyos explains that "we imagine the global as we imagine everything else: through metaphor, narrative, image, and related means" (22). Fiction that navigates the world broadens our consciousness that such a world exists as an interconnected whole. Alemán's collection does that precisely: it shows that Latin America, Europe, and the other locations her stories visit are linked through a network of multiple and constant exchanges. As such, La muerte silba un blues engages with issues at the core of the study of world literature.

Drawing on Pheng Cheah, I see world literature as literature that is an active power in the making of the world. He defines the "world" not only as a spatio-geographical entity but also as "an ongoing dynamic process of becoming," something that is continually being made and remade (42). In this sense, Cheah's definition of world literature as writing able to play a role in the ongoing creation of the world steps away from other conceptualisations primarily focused on "how literature operates as a real object of exchange and circulation in the world and constitutes a world of its own that transcends national boundaries and operates with its own specific laws and logic" (27). As such, his framework enables readings that consider the worldly potential of La muerte silba un blues even when, as an object of exchange and circulation, its reach remains limited to Spanish-speaking audiences.

The inclusion in the B39 list raised Alemán's celebrity, as Riofrio rightly points out. However, in 2010 he was already arguing that while Alemán's books have found praise and support in Ecuador and some of her works have been translated into several languages, broader circulation of her writing has been limited by the fact that her novels are yet to appear in English (16). Since then, one of Alemán's novels, Poso Wells (2007), was translated into English and published by the San Francisco-based City Lights in 2018. The majority of her oeuvre, however, remains exclusive to readers of Spanish. This is the case with $L a$ muerte silba un blues. It is an important fact to highlight because translation is often considered a critical currency to measure the effectiveness of a work of literature in a world setting, especially in the scholarship Cheah presents his position against. In this area, David Damrosch has famously argued that "works 
become world literature when they gain on balance in translation, stylistic losses offset by an expansion in depth as they increase their range" (289). In Damrosch's terms, the "depth" of Alemán's collection is yet to be expanded by translation and is yet to become world literature fully. Nonetheless, my point here is that even if it were to remain forever untranslated, La muerte silba un blues informs a representation of the world. As such, it already possesses a world literary stance. But perhaps more importantly, and the point I develop in the next section of this essay, it affects how we see the world.

\section{Ecuador at the Centre of the World}

Central to Pheng Cheah's interrogation of contemporary world literature theories is the question of what a world actually is. His work explores that question from the perspective of "narrative literature from the postcolonial South that attempts to remake the world against capitalist globalisation" (2). This section borrows from the idea that postcolonial literatures remake the world in an alternative fashion. This is a vital issue to analyse the work of a writer who has expressed her awareness of writing from a particular place of enunciation. "Yo no puedo obviar que escribo desde donde escribo" (I cannot ignore that I write from the place I write), Alemán declared when interviewed about her willingness to address Latin American and Ecuadorian history in her narrative, as opposed to following a common cosmopolitan concern that - in her view - dominates Latin American letters today (Licata). Alemán's declaration is helpful to reflect on what world La muerte silba un blues enables us to imagine when we see the collection as the product of a writer who, on the one hand, takes on the methods of a European filmmaker; while on the other, intentionally builds on Ecuador's history. Such duality echoes Kwame Anthony Appiah's notion of rooted cosmopolitanism by identifying a larger ensemble to engage with, but simultaneously recognising that the engagement is mediated by the realisation of the value of local allegiances (xiv). However, as I explain later on, I place my argument in the context of a Latin American criticism concerned with acknowledging the specify of context to rethink world literature.

The first part of this essay presented La muerte silba un blues as a collection that, in its structural relation with cinema, articulates globality. This implies an engagement with world literature theory that leads me to the second part of this essay, where I close read one of those stories to argue that Alemán's positionality marks her globality. My reading of El extraño viaje, the collection's opening title, pays close attention to the way in which Alemán foregrounds the city of Quito to place Ecuador at the centre of a global narrative. Or, more pre- 
cisely, at the centre of a Martian invasion. The story I revise revolves around a radiophonic adaptation of H.G. Wells' widely influential novel The War of the Worlds (1898), broadcast in Ecuador in 1949. Unlike the original plot where the main target of an attack by invaders from Mars is London, or the subsequent Orson Welles' radio drama (1938) in which the tripod fighting machines focus on New York City, in Alemán's version the extraterrestrial assault heads towards Quito.

El extraño viaje presents the first-person account of a radio drama writer in a popular station in Quito. Set in the late 1940s, the story starts when the director of the station gives the writer full artistic license to narrate and record, before it happens, a prominent boxing match to take place in the capital. The recording is broadcast as if it was the real fight to distant locations in Ecuador where, unverified, it passes down as fact. Handsomely rewarded for his effort, the protagonist continues his work by adapting the script of Orson Welles' radiophonic version of The War of the Worlds to the local context. Presented as truth by allegedly on-site reporters, the airing begins with a breaking news report on the destruction of Latacunga, a small city in the Ecuadorian highlands, attacked by a fleet of unidentified flying objects firing laser weapons. The reports highlight that the attackers are headed to Quito and continue through several transmissions as the invaders approach Ecuador's capital, violently eliminating the futile resistance they encounter after landing:

Something slippery is emerging from the shadows; it looks like an enormous grey snake. Or several of them. Or tentacles (...) The army is closing in, some soldiers in tanks. Wait, something is happening. The figure straightens up and raises something that, from where we are, resembles a mirror. A flame is going after the tanks! Oh my god, I can't believe it! The soldiers are scorching like paper figurines.

ALEMÁN 37

When voice actors are brought in to personify Ecuador's Minister of Defence and Quito's mayor calling for residents to be ready to defend or evacuate the city, the story portrays a community on the brink of chaos. Tuned in to the radio, locals all over the capital run out on the street in panic:

The street had become an overflowing river where hundreds of salmons tried to climb against the current to their salvation. Sleepy women and children dragged packages, baskets and poorly closed suitcases down Esmeraldas Street, towards the Pichincha, towards the bowels of the volcano where, protected by the darkness, they could perhaps escape from 
the alien attack. Descending by the same river, heading to where the lighting faded, men armed with sticks, torches, and rifles marched in the direction of the city's limits. They were going - it was not difficult to imagine to their deaths, their faces crossed by resignation.

ALEMÁN 36

Upon realising that the hoax is out of control, the protagonist witnesses the crowd's rage after learning that they were fooled. An angry mob goes to the radio station from where the broadcast takes place and sets the building on fire, while the emergency services refuse to intervene. The narrator survives the attack, yet many of his co-workers do not. He then goes home to wait for the Police to come looking for him, which never happens.

There is much to unpack in El extraño viaje, beginning with the fact that it fictionalises a real event. In 1949, a radio drama version of The War of the Worlds was indeed broadcast in Ecuador's capital. Radio Quito, the airing station, was destroyed in a fire started by angry listeners who felt fooled by the show's dramatization. News reports on the number of victims resulting from the incident vary, pointing to a number of between five and eight casualties (Avilés Zambrano). Contemporary readings of the event refer to motifs typical of invasion literature, e.g. fear of foreign threats, especially in the aftermath of Ecuador's 1942 war with neighbouring Peru and the broader context of the US hunt for communists in Latin America (Becker 2). Media Studies, on their part, focus on radio's capacity to inform and provoke fear-induced responses from audiences (Checa Godoy 108). My reading of Alemán's fictional version of the incident, however, is guided by the literature/cinema dialogue that La muerte silba un blues entails. The story's reference to Jess Franco offers clues to lay bare its engagement with - and its meanings for - world literature.

Franco has a prominent acting role in his fellow countryman Fernando Fernán Gómez's El extraño viaje (1964). The film, which Steven Marsh considers a "neglected masterpiece," depicts life in a provincial Spanish town where "contemporaneous history and a different past national history merge" (138). Franco plays the part of Venancio, a middle-aged man who unwittingly kills his older sister, Ignacia. The principal action follows the visiting Madrid-based musician Fernando as he helps Venancio get rid of Ignacia's body by dumping it in a wine vat and hiding the crime by cross-dressing as Ignacia, so nobody would suspect that a murder has taken place when they are seen leaving the town together. Marsh identifies a long-standing image of Spain's literary history in the depiction of the fictional town where the murder mystery develops. As a concept, he argues, the Spanish pueblo has long been "the subject of a 'utopian' idea that captures the essence of nationhood. The Spanish pueblo is the unpredictable 
'home' at the centre of the nation's Arcadian imagination" (135). Yet the film undoes the image of the pueblo by making it a place where national borders and traditions are breached "by the material of music and dress, through the activity of bricolage and new combinations of indigenous elements with those emanating from the United States, France, and Italy" (147). The cross-dressing plot serves as an allegory to argue that the pueblo itself is travestied, and its status as embodiment of the national is thus destabilised.

Fernán Gómez's film relates to Alemán's El extraño viaje in that they both present a national space destabilised by the permeability of its borders. In Alemán's story, Quito is the heart of Ecuador's national and political life, the city that needs to be defended for the nation to survive. At the same time, it is a place where global narratives converge. Wells, a British writer that Alemán is fascinated with (her 2007 novel, Poso Wells, continues Wells' 1904 short story The Country of the Blind in the twenty-first century). Not only one of the most iconic filmmakers of all time, Welles is also the mastermind behind the radiodramatized Martian attack of New York City. And finally Franco, Welles' collaborator in Europe as well as the filmmaker who informs the La muerte silba un blues as a whole. They all meet in an Ecuadorian capital traversed by The War of the Worlds' enduring popular culture impact: thanks to multiple adaptations, retellings and processes of hypertextuality, in the 117 years since its original publication, the novel has become not only a reference for literature but also for cinema, video games, music, radio, comic books, graphic novels and television. In this sense, while remaining at Ecuador's heart, Quito also becomes central to an international multimedia narrative. Being "in the middle," the story suggests, is only natural given the city's geographical location:

Our sources tell us that they are headed to Quito. Attention! We repeat, they are headed to Quito ... What is really alarming is that the spaceships are coming to the capital. It should not surprise us, though; the middle of the world's magnetic force is well known. If an extraterrestrial attack had to come, it had to be logical that it started in Ecuador; and it seems that's what's happening right now.

ALEMÁN 33

As the city's branding happily reminds its visitors, the Metropolitan District of Quito is partly located on the equator line, from which Ecuador takes its republican name. One of the country's most visited places is, in fact, the touristic complex Ciudad Mitad del Mundo (Middle of the World City), where a monument commemorating the 1735 French Geodesic Mission stands. Nevertheless, El extraño viaje's reminder that Ecuador is located in the centre of the planet 
contrasts with Ecuador's place in world literature theories that reproduce a centre-periphery model for organising the world literary field. I refer not only to Pascale Casanova's paradigmatic world republic of letters and its European capital but to all those mapping onto geopolitical structures where "one important conversation on the world stage is between Western Europe and the United States, while the rest of the world mostly listens" (Hoyos 19o). These frameworks match works of literature with circuits of global commerce marked by uneven economic relations among countries, especially to the detriment of those from the Global South. In this light, what being part of that "rest of the world" means for Latin American literature in general, and Ecuadorian literature in particular, is to be positioned in a periphery that regularly depends on interacting with European or North American centres for international circulation, translation and literary recognition.

El extraño viaje highlights Quito's geographical location to reinforce its point about Ecuador's global relevance in the face of a Martian invasion. The story refers to the "Mount Jennings Observatory in Chicago" - a fake astronomical site taken from Welles' script - to announce that, even if it is only temporary make-believe for naive radio listeners, the future of the planet might be in Ecuadorian hands. Being the first line of Earth's defence, Quito must come to terms with its newly found central place in the world order. Ecuador's capital is then given equal footing with the metropolises most commonly associated with H.G. Wells' tale, i.e. London, because of the original plot (and its countless reincarnations in British media, most recently the 2019 BвC's miniseries The War of the Worlds); and New York, because of Welles' radio adaptation (and, among others, the 2005 Steven Spielberg's blockbuster War of the Worlds). By putting forward that, rather than in the UK or the US, a planetary invasion that could end the world may well start in Ecuador, a narrative that also builds on a long literary and cinematic history and an enduring legacy in popular culture, Alemán's work gives new meaning to the social space it represents. That is to say, it repositions Ecuador into the forefront of global attention, imagining the possibility of a world centred on Latin America.

Foregrounding Ecuador's place in the world signals a decentring and recentring of world literature that, primarily concerned with following works of literature across national boundaries, defines the world as the expression, field, and product of transnational market exchange (Cheah 5). In Alemán's story, the world is instead the product of the destabilisation of the centre-periphery order by means of fiction. This alternative world exists as an interconnected whole yet is built through a profound understanding of the national experience from which it emerges. My point here is that, for remaking the world, El extraño viaje is acutely aware of Ecuador's history and positionality. Alemán's story reads as 
a deeply rooted national tale, a fictionalisation of the events of 1949 in which it is possible to find references to real-life characters (the protagonist is, for example, an unnamed version of the Ecuadorian writer Leonardo Páez, who orchestrated the original Radio Quito's drama). But it also reads like a story that takes its representational exercise further, building on the national history it refers to set up an intricate multi-layered network that connects Quito with London and New York and places Ecuador at the centre of the world. Thereby, El extraño viaje becomes fiction that builds on the national for imagining and informing an alternative representation of the global.

Building the global through the national means expanding current understandings of world literature, which too often discard the nation's relevance to thinking of the world as a whole. Franco Moretti claims that part of "the beauty" of world literature is that it goes against the grain of national historiography. He argues against close reading because, as a time-consuming practice, it is a limiting approach: "you invest so much in individual texts only if you think that very few of them really matter" (Moretti 57). Instead, the Italian critic advocates for distant reading, i.e. a type of literary analysis that, to expand the scope of limited canons, calls us "to focus on units that are much smaller or much larger than the text: devices, themes tropes - or genres and systems" (57). Using this method, and in order to understand literature as a global system, Moretti proposes that one must identify a unit of analysis and follow its different incarnations through a variety of environments "until, ideally, all of literary history become a long chain of related experiments" (62). This way, national histories are set aside in favour of framing the entirety of the world literary system. The purpose of the study of world literature, Moretti holds, is to be a permanent intellectual challenge to national literatures.

Alemán's work, on the other hand, suggests that dismissing the nation is not the only path for approaching world literature. Beyond echoing Appiah's rooted cosmopolitanism, my argument here also resonates with the work of scholars who - particularly from Latin American perspectives - have considered the role of contexts for thinking critically of world literature. In this line, Marta Puxan-Oliva and Annalisa Mirizio have argued for paying attention to the ways in which, whether real or symbolic, territories "intervene as a constructive element in literary creation as well as in its critical reception, in the politics of translation and its circuits"(Puxan-Oliva and Mirizio 3). By drawing on Latin American and Spanish experiences, their work recognises "the need for World Literature Studies to introduce new categories determined by the specificity of context" (7). Puxan-Oliva and Mirizio refer, for instance, to Álvaro Fernández Bravo's examination of Juan L. Ortiz, an Argentinean poet who spent most of his life in the province of Entre Ríos, which he took as one of his main liter- 
ary topics. Fernández Bravo discusses how Ortiz embraced Chinese poetry as a source of writing to argue that his poetry "shows the province as a position from which to look at the world, and interact with it"(Fernández Bravo 129). Even though, in this case, the province becomes a space alternative to the nation, Fernández Bravo's argument exemplifies the potential of thinking in world literature contextually. In Latin American writing and its subsequent criticism, the world is imagined; yet it is imagined from a particular place of enunciation, and as such, it is embedded in - and shaped by - the particular histories of such place.

To the scholarship aforementioned, one must include the work of Héctor Hoyos, Mariano Siskind, Ignacio Sánchez Prado and other scholars who have stressed the role of the region's literature as a source of alternative knowledge for world literature. My analysis enriches these discussions by providing evidence from the Ecuadorian case, which is still largely absent from the cartographies of Latin American world literature. Shedding light on one intersection of literature and cinema, I have discussed La muerte silba un blues as a collection of stories that sets up an interdisciplinary dialogue with Jess Franco to articulate globality; and Elextraño viaje as a story that reflects on Ecuador to refashion the world. Together, they demonstrate that we can focus on national contexts while engaging with their global dimensions. Doing so is possible because Latin America is deeply connected with the world beyond its boundaries. Hence, if a work of literature reflects and makes sense of contemporary Ecuador, it also reflects and makes sense of how Ecuador interacts with the world at large. Writers like Alemán show that national contexts do not necessarily go away when writing actively conveys globality and reimagines the world. Her work makes a case for a study of world literature that needs not be the study of the global exclusively, where national historiographies are overcome and buried; rather, it shows us that world literature can also be the study of the global by thinking through national historiographies.

\section{Works Cited}

Alemán, Gabriela. La muerte silba un blues. Bogotá: Penguin Random House, 2014. ePub Edition.

Appiah, Kwame Anthony. Cosmopolitanism:Ethics in a World of Strangers. London: Penguin Books, 2007.

Avilés Zambrano, Freddy. "El pánico por los marcianos se apoderó de Quito hace 70 años." El Universo 12 Feb. 2019. Web. 19 Jan. 2021.

Becker, Marc. The cIA in Ecuador. Durham: Duke UP, 2020. 
Botting, Fred. Gothic. London: Routledge, 1996.

Casanova-Vizcaíno, Sandra and Inés Ordiz. "Latin America, the Caribbean, and the Persistence of the Gothic." In Latin American Gothic in Literature and Culture. Eds. Sandra Casanova-Vizcaíno and Inés Ordiz. New York: Routledge, 2018, 1-13.

Cheah, Pheng. What is a World? On Postcolonial Literature as World Literature. Durham: Duke UP, 2016.

Checa Godoy, Antonio. "El miedo a Marte y la radio." In The End: el apocalípsis en la pantalla. Ed. Jesús Jiménez-Varea. Madrid: Fragua, 2009, 103-121.

Damrosch, David. What is World Literature? Princeton: Princeton UP, 2003.

Fernández Bravo, Álvaro. “An Episode in Provincial Cosmopolitanism:Juan L. Ortiz and Chinese Poetry." Journal of World Literature 2:1 (2017), 118-31.

Hoyos, Héctor. Beyond Bolaño: The Global Latin American Novel. New York: Columbia UP, 2015 .

Lázaro-Reboll, Antonio and Ian Olney. The Films of Jess Franco. Detroit: Wayne State UP, 2018.

Licata, Nicolás. "Detrás de la cortina de Humo: entrevista a Gabriela Alemán." Confabulario 10 Feb. 2018. Web. 20 Feb. 2021.

Lucas, Tim. "Jess Franco's Declaration of Principles: How to Read the Early Films, 195967." Video Watchdog 157 (2010), 16-49.

Marsh, Steven. “The Pueblo Travestied in Fernán Gómez's El extraño viaje (1964)." Hispanic Research Journal 4:2 (2003), 133-149.

Medina Cordova, Luis. Where are the borders? (Re)Imagining the Nation in Contemporary Ecuadorian Literature. 2020. King's College London. PhD Dissertation.

Moretti, Franco. “Conjectures on World Literature." New Left Review 1 (2000), 54-68.

Pavlović, Tatjana. Despotic Bodies and Transgressive Bodies: Spanish Culture from Francisco Franco to Jesus Franco. New York: State University of New York Press, 2002.

Pavlović, Tatjana. “Latent Durability in Jess Franco's Films.” In The Films of Jess Franco. Eds. Antonio Lázaro-Reboll and Ian Olney. Detroit: Wayne State UP, 2018, 113-39.

Puxan-Oliva, Marta and Annalisa Mirizio. "Rethinking World Literature Studies in Latin American and Spanish Contexts." Journal of World Literature 2:1 (2017), 1-9.

Riofrio, John D. "When the First World Becomes the Third: The Paradox of Collapsed Borders in Two Novels by Gabriela Alemán." MELUs 35:1 (2010), 13-34.

Sánchez Prado, Ignacio. Strategic Occidentalism: On Mexican Fiction, the Neoliberal Book Market, and the Question of World Literature. Evanston: Northwestern UP, 2018.

Siskind, Mariano. Cosmopolitan Desires: Global Modernity and World Literature in Latin America. Evanston: Northwestern UP, 2014.

Stam, Robert. World Literature, Transnational Cinema, and Global Media: Towards a Transartistic Commons. London: Routledge, 2019.

Todd, Kristofer. Jess Franco: The World's Most Dangerous Filmmaker. Eureka: Stark House Press, 2018. 